Pietro Sampaio BARUSELLI ${ }^{1}$; Ed Hoffman MADUREIRA'; Valquíria Hippollito BARNABE' ; Renato Campanarut BARNABE ${ }^{1}$; Rodolfo Cassimiro de Araújo BERBER ${ }^{1,2}$

Correspondência para:

PIETRO SAMPAIO BARUSELLI

Departamento de Reprodução Animal

Faculdade de Medicina Veterinária e Zootecnia da USP

Avenida Prof. Orlando Marques de Paiva, 87

Cidade Universitária Armando Salles de Oliveira

05508-270 - São Paulo - SP

e-mail: barusell@usp.br
Recebido para publicação: 15/11/2002 Aprovado para publicação: 17/09/2003

\section{Evaluation of synchronization of ovulation for fixed timed insemination in buffalo (Bubalus bubalis)}

\section{Avaliação da sincronização da ovulação para inseminação artificial em tempo fixo em bubalinos (Bubalus bubalis)}

\author{
${ }^{1}$ Departamento de Reprodução Animal da Faculdade de \\ Medicina Veterinária e Zootecnia da USP, São Paulo - SP \\ ${ }^{2}$ Departamento de Zootecnia da Fundação Faculdades Luiz \\ Meneghel, São Paulo - SP
}

\section{Summary}

The objective of this study was to evaluate the efficiency of synchronization ovulation protocol $\left(\mathrm{GnRH} / \mathrm{PGF}_{2} \alpha / \mathrm{GnRH}\right)$ for fixed timed insemination in buffalo. In Experiment 1, thirty-three female buffaloes with 60 days postpartum, were divided in two groups for evaluation of the follicular dynamics (Group 1, $\mathrm{n}=$ $16,10 \mathrm{mg}$ of $\mathrm{GnRH} / 15 \mathrm{mg}$ of $\mathrm{PGF}_{2} \alpha / 10 \mathrm{mg}$ of $\mathrm{GnRH}$; Group 2, $\mathrm{n}=17,20 \mathrm{mg}$ of $\mathrm{GnRH} / 15 \mathrm{mg}$ of $\mathrm{PGF}_{2} \alpha / 10 \mathrm{mg}$ of $\mathrm{GnRH}$ ). Ultrasonography exams were performed every 12 hours to verify the ovarian response to the first $\mathrm{GnRH}$ injection. Another evaluations were performed on $\mathrm{PGF}_{2} \alpha$ injection and second $\mathrm{GnRH}$ injection. After last hormonal injection, ultrasonography exams were performed every 6 hours to verify the moment of the ovulation. Blood samples were collected on Days 0, 7 and 9 to evaluate the progesterone concentrations at the moment of the hormonal injections. In Experiment 2, the efficiency of the synchronization of ovulation was verified for fixed timed insemination ( 16 hours after second GnRH injection, $n=1053$ ), during the favorable and unfavorable reproductive season, in the years of 1998 and 1999. Animals received $20 \mathrm{mg}$ of $\mathrm{GnRH} / 15 \mathrm{mg}$ of $\mathrm{PGF}_{2} \alpha / 10 \mathrm{mg}$ of $\mathrm{GnRH}$. Besides, also recorded and evaluated aspects like body condition score, parity, postpartum period, year and the reproductive season (favorable or unfavorable season), on the conception rate. In Experiment 1, it was verified that $33.0 \pm 8.3 \mathrm{~h}$ after the first $\mathrm{GnRH}$ injection, $60.60 \%$ of the animals ovulated (Group $1=70.5$ vs. Group $2=50.00 \%$; P >0.05). The dose of $\mathrm{GnRH}(10 \mathrm{mg}$ vs. $20 \mathrm{mg}$ ) and the progesterone concentration did not interfere in ovulation in the beginning of the treatment $(\mathrm{P}>0.05)$. Animals that ovulated $(\mathrm{n}=20)$ after the first $\mathrm{GnRH}$ injection presented larger follicular diameter $(\mathrm{P}<0.01)$ that those that no ovulated ( $n=13)$. In $\mathrm{PGF}_{2} \alpha$ injection, the follicular diameter was $10.3 \pm 2.0 \mathrm{~mm}$. The Group 1 presented larger follicular diameter than the Group $2(\mathrm{P}<0.01)$. Animals that ovulated after the first $\mathrm{GnRH}$ injection $(\mathrm{n}=20)$ presented higher progesterone concentrations in the day of $\mathrm{PGF}_{2} \alpha$ injection $(\mathrm{P}<0.05)$. It was observed that $78,80 \%$ female buffaloes treated presented synchronized ovulation and, the first dose of GnRH did not
Key-words Synchronization of ovulation. $\mathrm{GnRH}$. Buffalo. Ovsynch. 
interfere in the efficiency of the protocol $(\mathrm{P}>0.05)$. In Experiment 2 , it was observed conception rate of $45.40 \%(n=1053)$. Animals synchronized during the favorable reproductive season presented better conception rate than the unfavorable season $(48.80 \% \mathrm{vs}$. $6.90 \%$; $<<0.05)$. The conception rate was influenced by body condition score of the animals and parity during the favorable reproductive season $(\mathrm{P}<0.05)$. The conception rates did not differ according to the year (1998 and 1999) of artificial inseminations and the postpartum period in the beginning of the treatment $(\mathrm{P}>0.05)$. In summary, the Experiments indicated that the use of synchronization of the ovulation for fixed timed insemination, during the favorable reproductive season, presents satisfactory results in buffalo and could still be better when used multiparous buffaloes with good body conditon score in the beginning of the treatment.

\section{Introduction}

The efficiency of the synchronization of the ovulation for fixed timed insemination has been demonstrated by several groups of researches in bovine ${ }^{1}$. The synchronization of the wave of follicular growth, as well as the induction of the ovulation for the GnRH injection ${ }^{2}$ have result in satisfactory conception rates in programs of fixed timed artificial insemination (AI) in bovine $e^{3}$.

The GnRH injection, at any phase of the estrous cycle, results in a peak of LH that promotes the ovulation of follicles $>9.0 \mathrm{~mm}^{4}$ or luteinization of non-viable follicles, and a new wave of follicle growth emerges 2 or 3 days later. 5 . With the ovulation or luteinization of the dominant follicle, the levels of progesterone will remain high; therefore $\mathrm{PGF}_{2} \alpha$ was given on Day 7 to induce luteolysis and promote the ovulation of the follicle of the new wave of follicular growth 4 . The second GnRH injection was recommended after 48 hours of $\mathrm{PGF}_{2} \alpha$ injection for better synchronization of ovulation and to allow the fixed timed insemination.

As similar to bovine, the use of the synchronization of ovulation for fixed timed inseminated in buffalo present several advantages, once the AI program implantation in buffalo is more difficult. Animals do not have homosexual behavior during estrus, making it necessary to use teaser bulls? Furthermore, the buffalos present variable periods of mounting acceptance ( 6 at 48 hours). Since the AI in buffalo is performed at the end of estrus.

However, there is shortage information about the use of the synchronization of ovulation for fixed time inseminated in buffalo. Thus, the objective of this study was to evaluate the follicular dynamics and the efficiency of the Ovysnch protocol in buffalo.

\section{Material and Method}

\section{Animals}

Experiment 1 was performed in Registro - SP (latitude 244ㄱ'S; longitude $\left.47^{\circ} 43^{\prime} \mathrm{W}\right)$ during the first semester of 1998 in favorable reproductive season ${ }^{8}$. For evaluation of the follicular dynamics were used 33 female buffaloes with 60 days postpartum. Animals presented, at the beginning of the treatment, good body condition score $(>3,0$; scale from 1 to 5$)$. For evaluation of the efficiency of the protocols to field (Experiment 2), 1053 female buffaloes (southeast area of Brazil), during the favorable reproductive season (autumn and winter) and unfavorable (spring and summer), during1998 and 1999. In the time of experiments, the animals were maintained to pasture regime with mineral salt support. 
Experiment 1. Evaluation of follicular dynamics during Ovsynch protocol in buffalo.

Ovysnch protocol

All animals were treated in random days of the estral cycle. The female buffaloes of the Group $1(\mathrm{n}=16)$ received 10mg of $\mathrm{GnRH}$ (Buserelin acetate, Conceptalß) and, seven days later, were injected $15 \mathrm{mg}$ of $\mathrm{PGF}_{2} \alpha$ (Luprostiol, Prosolvin ${ }^{\circledR}$ ). Two days after the $\mathrm{PGF}_{2} \alpha$ injection the animals received $10 \mathrm{mg}$ of $\mathrm{GnRH}$. All animals were inseminated 16 hours after last hormonal injection. Animals of Group $2(n=17)$ received the same treatment from those of Group 1, with difference just in the first dose of GnRH (20mg, Buserelin acetate, Conceptalß; Figure 1).

\section{Ultrasonography exams}

The follicular dynamics was monitored by ultrassonography (Pie Medical Scanner 480) with transretal probe of 5 and $7.5 \mathrm{MHZ}$. The ultrasonography exams were performed every 12 hours until 48 hours, to evaluate the ovarian response after the first $\mathrm{GnRH}$ injection. Also evaluations were performed in the day of $\mathrm{PGF}_{2} \alpha$ injection, and every 6 hours after the second $\mathrm{GnRH}$ injection, to precise the moment of the ovulation. The disappearance of the follicles previously identified $(>10 \mathrm{~mm})$ indicated the occurrence of the ovulation?.

\section{Blood samples for hormonal dosage}

At the moment of each hormonal injection (D0, D7 and D9), we collected blood samples from the jugular vein. The blood was centrifuged and the plasma was fronzen at $-20^{\circ} \mathrm{C}$ for later hormone analysis. We took samples to evaluate progesterone levels at the first $\mathrm{GnRH}$ injection (D0), at PGF $\alpha$ injection (D7) and at the second GnRH injection (D9). For hormonal analysis were used a commercial radioimmunoassay kit (DPC, Coat-acountä, Los Angeles, CA, USA) for the hormonal analysis.
Experiment 2. Evaluation of Ovsynch protocol for fixed timed insemination in buffalo.

Synchronization of ovulation protocol for fixed timed insemination

All animals were treated in random days of the postpartum period ( $>40$ days). The animals received $20 \mathrm{mg}$ of $\mathrm{GnRH}$ (Buserelin acetate, Conceptal) and, 7 days later, injected $15 \mathrm{mg}$ of $\mathrm{PGF}_{2} \alpha$ (Luprostiol, Prosolvin). Two days after $\mathrm{PGF}_{2} \alpha$ injection, the animals received $10 \mathrm{mg}$ of $\mathrm{GnRH}$ (Buserelin acetate, Conceptal). The artificial insemination was performed in fixed time, without estrus detection, 16 hours after the last $\mathrm{GnRH}$ injection (Figure 2).

For artificial insemination, semen departures were analyzed and approved according to the norms of the Brazilian School of Animal Reproduction ${ }^{10}$.

In this present experiment were evaluated the influence of body condition score (scale 1 to 5), parity, postpartum period to the beginning of the treatment, insemination order and the season of the insemination (favorable or unfavorable reproductive season), on the conception rate. The pregnancy was diagnosed 30 days after the inseminations by ultrasonography with a lineal probe of $5,0 \mathrm{MHz}$.

\section{Statistical analysis}

Chi-square test was used to analyze the binomial variables, the percentage of buffaloes that ovulated after the first injection and the second GnRH injections, the percentage of buffaloes with synchronized ovulation after the second GnRH injection, the percentage of buffaloes with concentration of progesterone $<1 \mathrm{ng} /$ $\mathrm{mL}$, percentage of buffaloes with follicle diameter $>8.0 \mathrm{~mm}$ at the time of the treatment and pregnancy rates. The ANOVA was used to evaluate the continuous variables (follicle size and progesterone concentration) for repeated measure. The T-test was used to evaluate the differences between means. 


\section{Figure 1}

Schedule of treatments used for synchronization of ovulation for fixed timed insemination in buffalo ( ${ }^{\mathrm{a} C o n c e p t a l}{ }^{\circledR}$, Hoescht Roussel Veterinária S.A, São Paulo, Brazil; bProsolvin®, Intervet, Curitiba, Brazil)

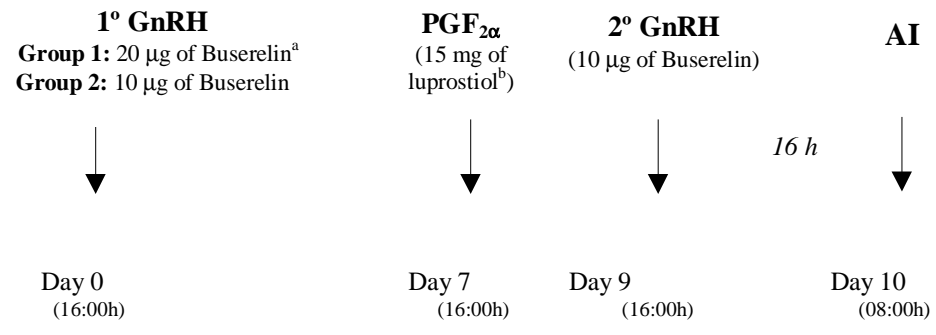

Figure 2

Schedule of treatments used for synchronization of ovulation for fixed timed insemination in buffalo ( ${ }^{\mathrm{a}} \mathrm{Conceptal} 囚$ ?, Hoescht Roussel Veterinária S.A, São Paulo, Brazil; 'Prosolvin®, Intervet, Curitiba, Brazil)

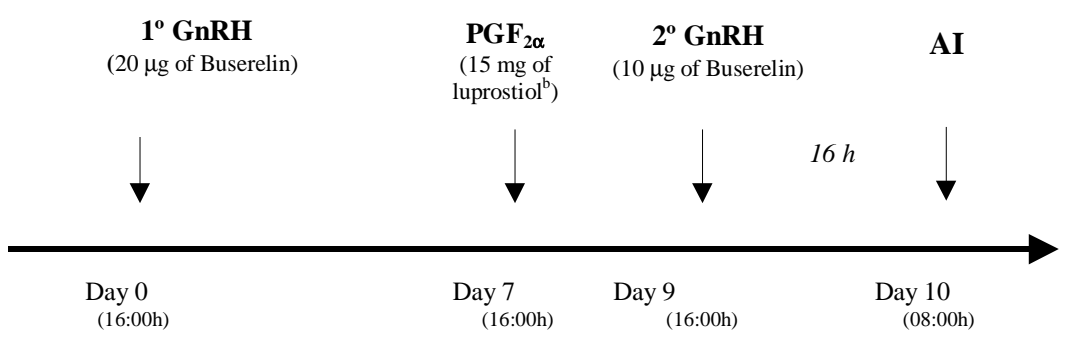

Figure 3

Distribution of the ovulations after the second GnRH injection (mean of 32,0 $\pm 5,7 \mathrm{~h}$ ), in female buffaloes ( $\mathrm{n}=26$ ) treated with the protocol of synchronization of ovulation with $\mathrm{GnRH} / \mathrm{PGF}_{2} \alpha / \mathrm{GnRH}$. São Paulo, 1998

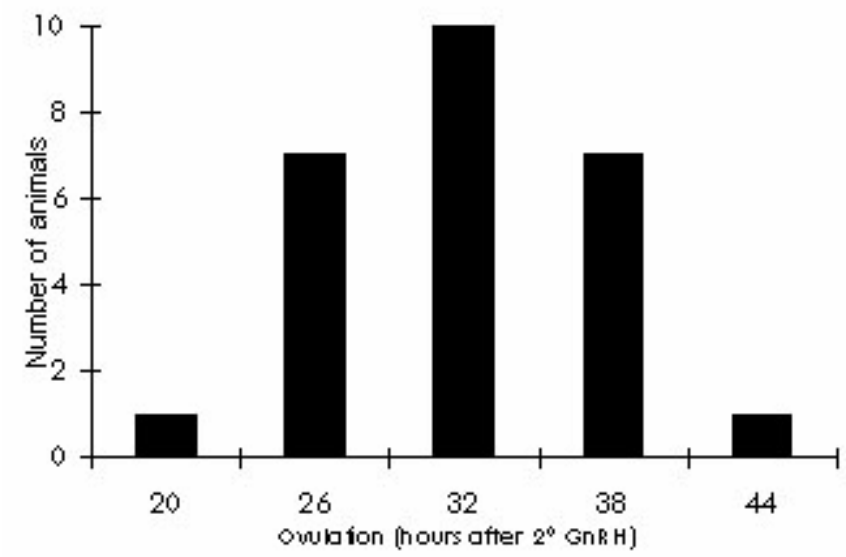

\section{Results}

Experiment 1. Evaluation of follicular dynamics during Ovsynch protocol in buffalo.

It was observed that $60,60 \%$ of the animals ovulated after the first
GnRH injection (Group $1=70.5$ vs. Group $2=50.00 \% ; \mathrm{P}>0.05)$. The interval between the first $\mathrm{GnRH}$ injection and ovulation was $33.0 \pm 8.3 \mathrm{~h}$ $(\mathrm{n}=20)$. The dose of GnRH $(10 \mathrm{mg}$ vs. $20 \mathrm{mg}$ ) did not interfere in the time 
Table 1

Effect of the first $\mathrm{GnRH}$ injection in the protocol of synchronization of ovulation with $\mathrm{GnRH} / \mathrm{PGF}_{2 \alpha} / \mathrm{GnRH}$ in buffalo. São Paulo, 1998.

\begin{tabular}{|c|c|c|c|}
\hline Ovul & tion to $1^{\circ}$ GnRH (Day 0) & No ovulation to $1^{\circ}$ GnRH (Day 0 ) & $\mathbf{P}$ \\
\hline Number of animals & $20 / 33(60.60 \%)$ & $13 / 33(39.40 \%)$ & \\
\hline Largest follicular diameter on Day $0(\mathrm{~mm})$ & $9.5 \pm 1.7$ & $6.9 \pm 2.4$ & $<0.002$ \\
\hline Largest follicular diameter on Day 7 (mm) & $9.0 \pm 1.3$ & $11.7 \pm 1.9$ & $<0.001$ \\
\hline Concentration of P4 on Day 7 ( $\mathrm{ng} / \mathrm{ml})$ & $2.56 \pm 1.02$ & $1.26 \pm 0.82$ & 0.0006 \\
\hline Ovulations synchronized after $2^{\circ} \mathrm{GnRH}(\%)$ & $90.0(18 / 20)$ & $61.5(8 / 13)$ & 0.06 \\
\hline Intervals between $2^{\circ} \mathrm{GnRH}$ and ovulation (h) & $33.9 \pm 4.9$ & $26.8 \pm 4.1$ & 0.001 \\
\hline Ovulations between Days 7 and $9(\%)$ & $5.0(1 / 20)$ & $30.8(4 / 13)$ & 0.06 \\
\hline Absence of ovulation after $2^{\circ} \mathrm{GnRH}(\%)$ & $5.0(1 / 20)$ & $5.8(1 / 13)$ & 0.64 \\
\hline
\end{tabular}

Table 2

Ovulation rate according to the progesterone concentration in the moment of the first GnRH injection in females buffaloes synchronized with GnRH/PGF $/$ /GnRH. São Paulo, 1998.

\begin{tabular}{ccc}
\hline Concentration of P4 (ng/mL) & Number of animals & Ovulation rate (\%) \\
\hline$<1.0$ & 15 & $66.6(10)$ \\
$>1.0$ & 18 & $55.5(10)$ \\
Total & 33 & $\mathbf{6 0 . 6 ( 2 0 )}$ \\
\hline
\end{tabular}

Tabela 3

Efficiency of synchronization of ovulation protocol with $\mathrm{GnRH}_{\mathrm{PGF}} / \mathrm{GnRH}$, according the dose of GnRH in buffalo. São Paulo, 1998.

\begin{tabular}{cccc}
\hline Dose of GnRH & $\begin{array}{c}\text { Synchronized } \\
\text { ovulation }\end{array}$ & $\begin{array}{c}\text { No Synchronized } \\
\text { ovulation }\end{array}$ & $\begin{array}{c}\text { Absence of ovulation } \\
\text { after } \mathbf{2}^{\circ} \mathbf{G n R H}\end{array}$ \\
\hline $10 \mathrm{mg}$ & $11 / 16(68.70 \%)$ & $4 / 16(25.00 \%)$ & $1 / 16(6.20 \%)$ \\
$20 \mathrm{mg}$ & $15 / 17(88.20 \%)$ & $1 / 17(5.90 \%)$ & $1 / 17(5.80 \%)$ \\
\hline Total & $\mathbf{2 6 / 3 3 ( 7 8 . 8 0 \% )}$ & $\mathbf{5 / 3 3 ( 1 5 . 1 0 \% )}$ & $\mathbf{2 / 3 3 ( 6 . 0 0 \% )}$ \\
\hline
\end{tabular}

Table 4

Conception rate of buffaloes synchronized with $\mathrm{GnRH}_{\mathrm{PGF}} / \mathrm{GnRH}$ and fixed timed inseminated, according to the reproductive season - São Paulo - 1998/1999.

\begin{tabular}{ccc}
\hline Reproductive Season & Number of animals & Conception rate (\%) \\
\hline Favorable & 967 & $48.8(472)^{\mathrm{a}}$ \\
Unfavorable & 86 & $6.9(06)^{\mathrm{b}}$ \\
\hline Total & 1053 & $\mathbf{4 5 . 4 ( 4 7 8 )}$ \\
\hline
\end{tabular}

$\left(\mathrm{a}^{1} \mathrm{~b} ; \mathrm{P}<0.05\right)$

Table 5

Conception rate of buffaloes synchronized with $\mathrm{GnRH} / \mathrm{PGF}_{2 \alpha} / \mathrm{GnRH}$ and fixed timed inseminated, according to the body condition score. São Paulo, 1998/1999.

\begin{tabular}{ccc}
\hline BCS & Number of animals & Conception rate (\%) \\
\hline$<3.0$ & 223 & $31.1(70)^{\mathrm{a}}$ \\
3.5 & 546 & $52.9(289)^{\mathrm{b}}$ \\
${ }^{3} 4.0$ & 198 & $57.1(113)^{\mathrm{b}}$ \\
\hline Total & $\mathbf{9 6 7}$ & $\mathbf{4 8 . 8 ( 4 7 2 )}$ \\
\hline$\left(\mathrm{a}{ }^{1} \mathrm{~b} ; \mathrm{P}<0.05\right)$ & &
\end{tabular}

Table 6

Conception rate of buffaloes synchronized with $\mathrm{GnRH} / \mathrm{PGF}_{2 \alpha} / \mathrm{GnRH}$ and fixed timed inseminated, according to the parity - São Paulo-1998/1999

\begin{tabular}{ccc}
\hline Parity & Number of animals & Conception rate (\%) \\
\hline Primiparous & 138 & $35.5(49)^{\mathrm{a}}$ \\
Multiparous & 829 & $51.0(423)^{\mathrm{b}}$ \\
\hline Total & $\mathbf{9 6 7}$ & $\mathbf{4 8 . 8 ( 4 7 2 )}$ \\
\hline$\left(\mathrm{a}^{1} \mathrm{~b} ; \mathrm{P}<0,05\right)$. & &
\end{tabular}


of ovulation $(30.7 \pm 8.7$ h for Group 1 and of $34.9 \pm 8.4$ h for Group $2, \mathrm{P}>$ $0.05)$. The progesterone level in the moment of the first $\mathrm{GnRH}$ injection did not interfere in the ovulation rate. Similars ovulation rate were observed for animals treated in absence $(66.60 \%)$ or in presence $(55.50 \%)$ of progesterone (Table 2). In the day of first $\mathrm{GnRH}$ injection, the mean of follicular diameter was $8.0 \pm 1.9 \mathrm{~mm}$ for female buffaloes of Group 1, and $8.7 \pm 2.7 \mathrm{~mm}$ for females of Group 2 $(\mathrm{P}>0.05)$. However, analyzing the groups jointly, it was observed that animals that ovulated $(n=20)$ after the first $\mathrm{GnRH}$ injection presented larger follicular diameter $(\mathrm{P}<0.01)$ that those that did not ovulate $(\mathrm{n}=13): 9.5 \pm 1.7$ vs $6.7 \pm 2.4 \mathrm{~mm}$, respectively.

At the day of $\mathrm{PGF}_{2}$ a injection, the mean of follicular diameter was $10,3 \pm 2,0 \mathrm{~mm}$ (0.7 to $1.5 \mathrm{~mm})$. The Group 1 presented larger follicular diameter that Group $2(11.2 \pm 1.7$ vs. $9.1 \pm 1.5 \mathrm{~mm} ; \mathrm{P}<0.01)$. Also was observed that the animals that ovulated after the first GnRH injection $(n=20)$ presented higher progesterone levels at the day of the $\mathrm{PGF}_{2}$ a injection (2.56 \pm 1.02 vs $1.26 \pm 0.82 \mathrm{ng} / \mathrm{ml}$; $<<0.05)$. Forty-eight hours after $\mathrm{PGF}_{2}$ a injection, all animals presented levels of progesterone less than $1 \mathrm{ng} / \mathrm{ml}$.

The interval between second GnRH injection and ovulation was 32.0 $\pm 5.7 \mathrm{~h}$ for the Groups 1 and 2. The animals that did not ovulated with the first $\mathrm{GnRH}$ injection presented smaller interval $(\mathrm{P}<0.01)$ between the second $\mathrm{GnRH}$ injection and ovulation that those that ovulated $(26.8 \pm 4.1 \mathrm{~h}$ vs. 33.9 $\pm 4.9 \mathrm{~h}$; Table 1). Also was possible to observe that the animals of Group 1 presented smaller interval than those of Group 2 (29.3 \pm 5.6 vs. $34.1 \pm 5.0 \mathrm{~h}$; $\mathrm{P}<0.05)$. Most of ovulations synchronized after the second GnRH injection occurred inside of a period of 12 hours $(92.3 \%$; 24/26; Figure 3$)$, and of 24 hours $(100.00 \% 26 / 26)$ for
Groups 1 and 2 when analyzed jointly. Twenty-six $(78,80 \%)$ animals treated presented synchronized ovulation (Group $1=62.70 \%$; Group $2=$ $88.20 \%), 6$ buffaloes $(15.10 \%)$ ovulated between $\mathrm{PGF}_{2}$ a injection and second GnRH injection, and 2 animals $(6.00 \%)$ did not ovulate after the end of the treatment (Table 3). The first dose of GnRH did not interfere (P>0.05) in the efficiency of the protocol, not being observed difference between Groups regarding the synchronized ovulation rates. However, results suggest tendency $(P=0.06)$ of better results in buffaloes that ovulated to the first GnRH injection than those did not ovulated (90.00 vs. $61.50 \%$, respectively; Table 1). Animals that did not ovulate to the first GnRH injection presented tendency to manifest premature ovulations between the $\mathrm{PGF}_{2} \mathrm{a}$ injection and the second $\mathrm{GnRH}$ injection (5.00 vs. $30.80 \%$; $P=0.06)$.

Experiment 2. Evaluation of Ovsynch protocol for fixed timed insemination in buffalo

The conception rate of $45.40 \%$ ( $n=1053)$ demonstrated response to the treatment hormonal. However, the animals synchronized during the favorable reproductive season presented better results than those animals synchronized during the unfavorable period ( $48.80 \%$ vs. $6.90 \%$; $\mathrm{P}<0.05$; Table 4). The conception rate was influenced by body condition score of animals synchronized during the favorable reproductive season ( $\mathrm{P}$ $<0.05)$. Animals with corporal score $>3,5$ presented better conception rate than buffaloes with corporal score $<$ 3.0 (Table 5). Similars conception rates were observed during the year 1998 and 1999 in that the artificial inseminations in fixed time they were performed [50.20\%, $\mathrm{n}=261$ (1998) vs. $48.3 \%, \mathrm{n}=706$ (1999); $\mathrm{P}>0.05]$.

Multiparous buffaloes presented better conception rates than 
the primiparous $(51.00 \%$ vs. $35.50 \%$, respectively; $\mathrm{P}<0.05$; Table 6$)$. The postpartum period did not interfere in the conception rate of the animals synchronized. The conception rate of the animals inseminated before 60 days was $50.90 \%$ (170/334); between 60 to 99 days was $48.20 \%(158 / 328)$, and above 100 days, of $47.20 \%$ (144/305; Table 6).

\section{Discussion}

Experiment 1. Evaluation of follicular dynamics during Ovsynch protocol in buffalo.

In response to synchronization of ovulation with $\mathrm{GnRH} / \mathrm{PGF}_{2} \mathrm{a} /$ $\mathrm{GnRH}$, many female buffaloes showed ovulation in short time of the end of the treatment (Experiment 1). Such results indicate that the fixed timed insemination in buffalo presents perspectives of good results, similarly previously observed in bovine by Pursley, Mee and Wiltbank². In Experiment 1 was observed ovulation rate of $60.60 \%$ after the first $\mathrm{GnRH}$ injection. Those results were lower than observed in bovine for Wiltbank ${ }^{11}$ $85.00 \%$ - and Pursley, Mee and Wiltbank ${ }^{2}-90 \%$. However, Berber, Baruselli and Madureira ${ }^{12}$ also demonstrated ovulation rate after the first GnRH injection $(86 \%)$, similary to results found in bovine. It is possible that results of Berber, Baruselli and Madureira ${ }^{12}$ have been influenced positively by the previous selection of the animals by body condition score ( $>$ 3,5; scale from 1 to 5), once Baruselli et al. ${ }^{13}$ observed better reproductive efficiency in female buffaloes with better corporal condition. For Martinez et al..$^{14}$, the ovulation rate after the $\mathrm{GnRH}$ injection is associated to the number of animals with dominant follicles, at growth phase, presents at the moment of the treatment. In Experiment 1, the follicular diameter at the moment of the injection influenced the ovulation rate after the administration of GnRH. Pursley, Mee and Wiltbank ${ }^{2}$ and MARTINEZ et al. ${ }^{14}$ observed larger follicular diameter in bovines that ovulated after first $\mathrm{GnRH}$ injection. Dominant follicles present larger number of receptors for LH in the granulosa cells ${ }^{4,15}$, promoting better ovulation rates. In Experiment 1, the progesterone concentration at the moment of the first GnRH injection did not interfere in the ovulation rate, indicating that is possible answer in similar rates in the absence or in the progesterone presence. Those results agree with Martinez et al. ${ }^{14}$, that observed high ovulation rate even in animals that were in the diestrus phase. Those results and the increase of the ovulatory rate suggest that the follicular status at the moment of the treatment has considerable influence on the ovulation rates of animals treated with $\mathrm{GnRH}$, in the presence and in the progesterone absence. Bodensteiner et al. ${ }^{4}$ and Pursley, Mee and Wiltbank ${ }^{2}$ demonstrated that the ovulation occurs from 30 to 32 hours after the GnRH injection in bovine. In buffalo, Beber, Baruselli and Madureira ${ }^{12}$ observed ovulation $36.4 \pm 10.4$ hours after the first $\mathrm{GnRH}$ injection. Such results, as well as the present experiment (33.0h $\pm 8.3 \mathrm{~h}$ ) suggest that in buffalo the interval between the first $\mathrm{GnRH}$ injection and ovulation is similar to that occurs in the bovine.

According to Rusbridge, Bramley and Webb et al. ${ }^{19}$, after 6 days of the GnRH injection $75.00 \%$ of the animals that ovulated presents formation of accessory corpus luteum. Similar results were verified by Marques et al. ${ }^{17}$, that report $100.00 \%$ of ovulation rate in heifers treated with GnRH, LH and hCG in the day 7 of the estrus cycle. Those authors observed increase in the concentrations of progesterone in the animals that ovulated, due to the formation of 
accessory corpus luteum. In the present experiment, the female buffaloes that ovulated after the first GnRH injection presented higher concentrations of progesterone at day of $\mathrm{PGF}_{2}$ a injection (Day 7) that those that did not ovulated $(2.56 \pm 1.02$ vs. $1.26 \pm 0.82$ $\mathrm{ng} / \mathrm{ml}$ ). Those results agree with findings in bovine that showed higher progesterone concentrations in animals with accessory corpus luteum ${ }^{2,16,17}$, and can indicate that the buffaloes that ovulated to the first GnRH injection had accessory corpus luteum.

The results of Experiment 1 demonstrated that animals that did not ovulate after the first GnRH injected presented shorter interval and fewer synchronized between the second GnRH injection and ovulation that those that ovulated. Those animals presented smaller synchronized ovulation similarly to Vasconcelos ${ }^{1}$ in bovine. For Dejarnette, Salverson and Marshall ${ }^{18}$, the efficiency of the treatment of synchronization of the ovulation depends on the ovarian response to the first $\mathrm{GnRH}$ injection, and they consider that ovarian response is a important factor of the protocol of synchronization of the ovulation for fixed timed insemination. In the present experiment were observed early ovulation, low synchronization of the ovulation and low progesterone levels on the Day 7 in animals that did not ovulate after the first GnRH injection. Such results showed that the absence of ovulation in the beginning of the treatment didn't synchronize the wave of follicular growth that promotes variation of the moment of the ovulation in the animals submitted to the protocol.

In bovine, $100.00 \%$ of the cows and $75.00 \%$ of the heifers ovulated between 24 and 32 hours after the second GnRH injection ${ }^{2}$ ). In the present experiment, the female buffaloes presented $78.80 \%$ of synchronized ovulations, with interval between the second GnRH injection and ovulation of $32.0 \pm 5.7$ hours. Most animals presented synchronized ovulation (interval of 12 hours), demonstrating the viability of ovulation synchronization in that species. Data found in this experiment are similar to findings for Fricke, Guenther and Wiltbank ${ }^{19}$ and Santos et al. ${ }^{20}$ and Vasconcelos et al. ${ }^{21}$, that observed synchronized ovulation to $80 \%$ after Ovysnch protocol.

The treatment with GnRH/ $\mathrm{PGF}_{2} \mathrm{a} / \mathrm{GnRH}$ in buffalo provided good synchronization of ovulation, differently that observed Porto-Filho et al. ${ }^{22}$ that just used $\mathrm{PGF}_{2} \mathrm{a}$. That observation was also reported in bovine $e^{2,5,23,24}$, and indicates that associating $\mathrm{GnRH}$ and $\mathrm{PGF}_{2}$ a presented better synchronization of the ovulation and the fixed timed insemination with success, without estrus detection.

Experiment 2. Evaluation of Ovsynch protocol for fixed timed insemination in buffalo

In the Experiment 2, the synchronization of ovulation for fixed timed insemination presented satisfactory results during favorable season (favorable season $=48.80 \%$ vs. unfavorable season $=6.90 \% ; \mathrm{P}<0.01$ ). Those results agree with the reduced reproductive rate during the unfavorable reproductive period verified by Zicarelli ${ }^{25}$. Some authors, described the reproductive seasonality of buffalo as an endocrinology variation due to the melatonin secretion during the year ${ }^{25}$. The results of this experiment demonstrated that during the favorable reproductive season, the synchronization of ovulation is perfectly viable in buffalo. In that period, the synchronization of the ovulation provided conception rate of $48.50 \%$ after a single insemination in 
fixed time. That conception rate is similar to those found in studies that insemination was performed 12 hours after the natural estrus detection ${ }^{7}$. Therefore, it can be suggested that the ovulations have been synchronized efficiently, presenting appropriate fertility. Treatment with GnRH induces inhibition of the estrus manifestation, with high number of silent ovulations ${ }^{24}$, the estrus symptoms of animals should not be considered in Ovsynch protocol.

The conception rate of female buffaloes inseminated had interference. The body condition score of the females to the beginning of the treatment. In this way, to increase conception rates, the animals should present body condition score $>3.5$ (scale from 1 to $5)$. Geary et al. ${ }^{3}$ studied the synchronization of ovulation in 220 bovine and demonstrated better conception rates in animals with better corporal condition. In bovine, Cavallieri and Fitzpatrick ${ }^{26}$ reported that the corporal condition influences the ovarian cyclicity, and treatments that control the estral cycle and the ovulation. Buffaloes inseminated after the natural estrus detection also have great influence of the body condition score in the reproductive efficiency ${ }^{13}$. Thus it is possible to suggest that the success of the synchronization of ovulation for fixed timed insemination in buffalo depends on the good selection of animals for the body condition score in the beginning of the treatment.

The difference between conception rates of primaparous and multiparous $(35.50 \%$ vs. $51.00 \%)$ demonstrated that the parity is a decisive factor in the efficiency of the protocol. Ferreira et $\mathrm{al}^{27}$ reported that primiparous spend energy for the continuity of the corporal growth, and multiparous converge that energy for the reproductive processes, guaranteeing ovarian cyclicity and reproductive activity ${ }^{26}$. Besides, Wetteman ${ }^{28}$ reported that the lack of available energy for the reproductive processes promoters the interruption of the estral cycles because of the reduction in the gonadotrophins secretion and decrease of the follicular growth. That suggests that primiparous presents some restriction in programs of synchronization of ovulation for fixed timed insemination.

The postpartum period in the beginning of the protocol of synchronization of ovulation for fixed timed insemination is important to obtain good conception rates. Processes involved in the uterine involution and ovarian activity depend directly on physiologic factors at the moment of the partum and during the postpartum period. However, Geary et al. ${ }^{3}$ observed that the synchronization of ovulation for Ovsynch method presents better results in inferior periods to 70 days postpartum. In agree that information, Pursley, Mee and Wiltbank ${ }^{2}$ found higher pregnancy rates to the 60 days postpartum in animals treated with the Ovsynch method than in Control Group (estrus detection). As the conception rates did not show difference between 40 to 60 days postpartum, it is possible to suggest that treatment can reduce interval among calves around of $12 / 13$ months, making possible that the genetic improvement is accompanied by the improvement of the reproductive acting.

In summary, the data demonstrate that the synchronization of the ovulation is possible for fixed timed insemination in buffalo during the reproductive season. However, to obtain better results should be used multiparous buffaloes with good corporal condition in the beginning of the treatment. 


\section{Resumo}

O objetivo desse estudo foi avaliar eficiência do protocolo de sincronização da ovulação $\left(\mathrm{GnRH} / \mathrm{PGF}_{2} \alpha / \mathrm{GnRH}\right)$ para inseminação artificial em tempo fixo em bubalinos. No Experimento 1, trinta e três búfalas com 60 dias pós-parto, foram separadas em dois grupos para avaliação da dinâmica folicular (Grupo 1, $\mathrm{n}=16,10 \mathrm{mg}$ de $\mathrm{GnRH} / 15 \mathrm{mg}$ de $\mathrm{PGF}_{2} \alpha / 10 \mathrm{mg}$ de GnRH; Grupo 2, n = 17, 20mg de GnRH/PGF 2 / $10 \mathrm{mg}$ de $\mathrm{GnRH}$ ). Exames ultra-sonográficos foram realizados de $12 \mathrm{em} 12$ horas para verificar a resposta ovariana à primeira aplicação de $\mathrm{GnRH}$. Outras avaliações foram realizadas nos dias da aplicação da $\mathrm{PGF}_{2} \alpha$ e do segundo GnRH. Em seguida, foram realizados exames de 6 em 6 horas até o momento da ovulação. Foram colhidas amostras de sangue nos dias das aplicações para avaliar as concentrações de progesterona no momento das administrações hormonais. No Experimento 2, foi verificada a eficiência da sincronização da ovulação para inseminação artificial em tempo fixo (16 horas após o segunda dose de $\mathrm{GnRH}, \mathrm{n}=1053)$, durante as estações reprodutiva favorável e desfavorável, nos anos de 1998 e 1999. Os animais receberam $20 \mathrm{mg}$ de $\mathrm{GnRH} / \mathrm{PGF}_{2} \alpha / 10 \mathrm{mg}$ de $\mathrm{GnRH}$. Ainda, foi analisada a influência da condição corporal, ordem de partos, período pós-parto ao início do tratamento, ano e a estação reprodutiva (favorável ou desfavorável), sobre a taxa de concepção. No Experimento 1, verificou-se que 33,0 \pm 8,3h após a primeira aplicação de $\mathrm{GnRH}, 60,60 \%$ dos animais ovularam (Grupo $1=$ $70,5$ vs. Grupo $2=50,00 \% ; \mathrm{P}>0,05)$. A dose de GnRH (10mg vs. $20 \mathrm{mg}$ ) e a concentração de progesterona no início do tratamento não interferiu na ovulação ( $\mathrm{P}>0,05)$. Os animais que ovularam (n $=20$ ) após a primeira aplicação de $\mathrm{GnRH}$ apresentaram maior diâmetro folicular $(\mathrm{P}<0,01)$ que aqueles que não ovularam $(\mathrm{n}=13)$. $\mathrm{Na}$ aplicação de $\mathrm{PGF}_{2} \alpha$, o diâmetro folicular médio foi de $10,3 \pm$ 2,0mm. O Grupo 1 apresentou maior diâmetro folicular que o Grupo $2(\mathrm{P}<0,01)$. Os animais que ovularam após a primeira aplicação de $\mathrm{GnRH}(\mathrm{n}=20)$ apresentaram maiores concentrações de progesterona no dia da aplicação da $\mathrm{PGF}_{2} \alpha(\mathrm{P}<0,05)$. Notouse que $78,80 \%$ dos animais tratados apresentaram ovulação sincronizada sendo que, a primeira dose de GnRH não interferiu na eficiência do protocolo $(\mathrm{P}>0,05)$. No Experimento 2, observouse taxa de concepção de 45,40\% $(\mathrm{n}=1053)$. Animais sincronizados durante a estação reprodutiva favorável apresentaram melhores taxas de concepção quando comparados ao período desfavorável $(48,80 \%$ vs. $6,90 \%$; P < 0,05). A taxa de concepção foi influenciada pela condição corporal dos animais e pela ordem de partos durante a estação reprodutiva favorável $(\mathrm{P}<0,05)$. As taxas de concepção não diferiram conforme o ano (1998 e 1999) de realização das inseminações artificiais e o período pós-parto no início do tratamento hormonal $(\mathrm{P}>0,05)$. Em conclusão, os Experimentos indicaram que a utilização da sincronização da ovulação para inseminação artificial em tempo fixo, durante a estação reprodutiva favorável, apresenta resultados satisfatórios em bubalinos, podendo ainda ser melhorados quando utilizadas búfalas multíparas com bom estado corporal no início do tratamento.
Palavras-chave

Sincronização da ovulação. GnRH.

Búfalos.

Ovsynch 


\section{References}

1- VASCONCELOS, J. L. M. Avaliação do protocolo de sincronização de ovulação "ovsynch" e de fatores relacionados à associação entre produção de leite e taxa de concepção. Jaboticabal, 1998, 128 f. Tese (Doutorado em...) - Faculdade de Ciências Agrárias e Veterinárias, Universidade Estadual Paulista, São Paulo, 1998.

2- PURSLEY, J. R.; MEE, M. O.; WILTBANK, M. C. Sinchonization of ovulation in dairy cows using $\mathrm{PGF}_{2} \alpha$ and $\mathrm{GnRH}$. Theriogenology, v.44, n. , p. 915-923, 1995.

3- GEARY, T. W.; WHITTIER, J. C.; DOWNING, E. R., LEFEVER, D. G.; SILCOX, R. W.; HOLLAND, M. D.; NETT, T. M.; NISWENDER, G. D. Pregnancy rates of postpartum beef cows that were synchronized using Syncro-Mate-B ${ }^{\circledR}$ or the ovsynch protocol. Journal Animal Science. v. 76, n. , p. 1523-1527, 1998.

4- BODENSTEINER, K. J.; KOT, K.; WILTBANK, M. C.; GINTHER. O. J. Synchronization of emergence of follicular wave in cattle. Theriogenology, v. 45, n. , p. 1115-1128, 1996.

5- TWAGIRAMUNGU, H.; GUILBAULT, L. A.; DEUFOUR, J. J. Synchronization of ovarian follicular waves with a gonodotropinreleasing hormone agonist to increase the precision of estrus in cattle: a review. Journal Animal Science v. 73, n. , p. 3141-3151, 1995.

6- DE RENSIS, F.; PETERS, A. R. The control of follicular dynamics by $\mathrm{PGF}_{2} \alpha, \mathrm{GnRH}, \mathrm{hCG}$ and oestrus synchronization in cattle. A review. Reproduction Domestic Animal. v. 34, n. , p. 49-59, 1999.

7- BARUSELLI, P. S.; VIANA, W. G.; MUCCIOLO, R. G.; OLIVEIRA, C. A.; MADUREIRA, E. H. Ovarian activity and sexual behaviour during postpartum period in buffaloes. In: WORLD BUFFALO CONGRESS, 4., 1994, São Paulo. Anais... São Paulo: s.e., 1994. v. 3, p.440-442.

8- BARUSELLI, P. S.; OLIVEIRA, J. F. S.; MENDES, M. L. M.; JORGE, A. M.; FUJII, T.; PALAZZO, J. P. C. Diagnóstico da bubalinocultura do Vale do Ribeira. Campinas. DocumentoTécnico CATI, v. 94 , 16 p., 1993.

9- NASSER, L. F.; ADAMS, G. A.; BO, G. A.; MAPLETOFT, R. J. Ovarian superovulatoy response relative to follicular wave emergence in heifers. Theriogenology, v.40, n. , p.713-724, 1993.

10- COLÉGIO BRASILEIRO DE REPRODUÇÃO ANIMAL. Manual para exame andrológico e avaliação de sêmen animal. 2. ed. Belo Horizonte, 1998. 45 p.

11- WILTBANK, M. C. How information on hormonal regulation of the ovary has improved understanding of timed breeding programs. In: ANNUAL MEETING OF THE SOCIENTY FOR THERIOGENOLOGY. número do evento. 1997, local. Proceedings... local publ.: editora, ano publ. p. 83-97.

12- BERBER, R. C. A.; BARUSELLI, P. S.; MADUREIRA, E. H. Avaliação do aproveitamento do estro subsequente à sincronização da ovulação com protocolos "OVSYNCH" (GnRH vs. LH) em bubalinos (Bubalus bubalis). Revista Brasileira de Reprodução Animal, v. 25, n. , p. 379-381, 2001.

13- BARUSELLI, P. S.; BARNABE, V. H.; BARNABE, R. C.; VISINTIN, J. A.; MOLEROFILHO, J. R.; PORTO, R. Effect of body condition score at calving on postpartum reproductive performance in buffalo. Buffalo Journal, v. 1, n. , p. 53-65, 2001.

14- MARTINEZ, M. F.; ADAMS, G. P.; BERGFELT, D. R.; KASTELIC, J. P.; MAPLETOFT, R. J. Effect of LH or GnRH on the dominant follicle of the first follicular wave in beef heifers. Animal Reproduction Science. v. 57, n., p. 23-33, 1999.

15- XU, Z.; GARVERICK, H. A.; SMITH, G. W. SMITH, M. F.; HAMILTON, S. A.; YOUNGQUIST, R. S. Expression of folliclestimulating hormone and luteinizing hormone receptor messenger ribonucleic acid in bovine follicles during the first follicle wave. Biology Reproduction. v. 53, n. , p. 951-957, 1995.

16- RUSBRIDGE, S. M.; BRAMLEY, T. A.; WEBB, R. A comparison of GnRH-induced corpora lutea and spontaneously formed $C L$ in heifers. Journal Reproduction Fertility, $v$. 9, n. , p. 33, 1992. Abstract series.

17- MARQUES, M. O.; MADUREIRA, E. H.; OLIVEIRA, C. A.; BO, G. A.; BARUSELLI, P. S. Avaliação ultra-sonográfica e concentração plasmática de progesterona em novilhas Bos taurus $x$ Bos indicus submetidas a diferentes tratamentos no dia 7 do ciclo estral. In: SIMPÓSIO INTERNACIONAL DE REPRODUCCIÓN ANIMAL, 4., 2001. Cordoba. Proceedings... 2001. v.1, p.265.

18- DEJARNETTE, J. N.; SALVERSON, R. L.; MARSHALL, C. E. Incidence of premature estrus in lactacting dairy cows and conception rates to studing estrus or fixed-time inseminations after synchronization using $\mathrm{GnRH}$ and $\mathrm{PGF}_{2} \alpha$. Animal Reproduction Science, v. 67, n. , p. 27-35, 2001.

19- FRICKE, P. M.; GUENTHER, J. N.; WILTBANK, M. C. Efficacy of decreasing the dose of GnRH used in a protocol for synchronization of ovulation and time $\mathrm{Al}$ in lactating dairy cows. Theriogenology, v. 50, p. 1275-1284, 1998.

20- SANTOS, R. M.; VASCONCELOS, J. L. M.; SILVA, E. P. B. C.; MENEGYETTI, M.; FERREIRA, N.; OLIVEIRA, C. A. Avaliação da 
eficácia de D-Cloprostenol ou Cloprostenol sódico e de diferentes doses de Gonadorelina $(0,10 \mathrm{mg}$ vs $0,25 \mathrm{mg})$ no protocolo "Ovsynch" em vacas holandesas. Revista Brasileira Reprodução Animal, v. 25, n. , p. 298-300, 2001.

21- VASCONCELOS, J. L. M.; SILCOX, R. W.; ROSA, G. J. M.; PURSLEY, J. R.; WILTBANK, M. C. Synchronization rate, size of the ovulatory follicle, and pregnancy rate after synchronization of ovulation beginning on different days of the estrous cycle in lactating dairy cows. Theriogenology, v. 52, n. , p. 1067-1078, 1999.

22- PORTO-FILHO, R. M.; BARUSELLI, P. S.; MADUREIRA, E. H.; MUCCIOLO, R. G. Detecção de cio em búfalas através do sistema de radiotelemetria. Revista Brasileira Reprodução Animal v. 23, n. , p. 356-358, 1999.

23- THATCHER, W. W.; MATTOS, R.; MOREIRA, F.; BINELLI, M.; AMBROSE, J. D. Experimental manipulation of follicular growth. Reproduction in Domestic Animals, p. 27-33, 1999. Supplement 6.

24- BARUSELLI, P. S.; MARQUES, M. O.; CARVALHO, N. A. T.; VALENTIM, R.; BERBER, R. C. A.; CARVALHO FILHO, A. F.; MADUREIRA, E. H.; COSTA NETO, W. P. Dinâmica folicular em novilhas receptoras de embrião bovino submetidas à sincronização da ovulação para inovulação em tempo fixo. Arquivos da Faculdade de Veterinária da Universidade Federal do Rio Grande do Sul, v. 28., p. 217, 2000. Trabalho apresentado à 15 . Reunião Anual da Sociedade Brasileira de Transferência de Embriões, Rio Quente, 2000.

25-ZICARELLI, L. Out-of-breeding-season mating technique in buffalo (OBSM). In: BUBALINOS: SANIDADE, REPRODUÇÃO E PRODUÇÃO, 1., Jaboticabal. 1999, Anais... Jaboticabal: editora, 1999. p. 179-202.

26- CAVALLIERI, J.; FITZPATRICK, L. A. Artificial insemination of Bos indicus heifers: the effects of body weight, condition score, ovarian cyclic status and insemination regimen on pregnancy rate. Australian Veterinary Journal, v. 72, n., p. 441-447, 1995.

27- FERREIRA, M. B. D.; LOPES, B. C.; ANDRADE, I. C.; CONCEIÇÃO, V. J. Escore corporal e anestro pós-parto em primíparas zebu. Revista Brasileira de Reprodução Animal. v. 21, n. 2, p. 114-116, 1997.

28- WETTEMAN, R. P. Management of nutricional factors affecting the prepartum and postpartum cow. In: FIELDS, J.M.; SAND, R.S. Factors afecting calf crop. Boca Raton: CRS Press, Inc. 1994, p. 155-165. 